\title{
Bledar Toska
}

University of Vlora

\section{Dialogizing Communication through Pragmatic Markers}

\author{
Summary
}

The paper discusses the meta-communicative features of pragmatic markers. Communication is approached from the Bakhtinian concept of dialogism, which is seen as a two-way process between interlocutors in speech.

In this view, the word is seen as a dialogical item that exists and gains meaning only in the context in which it is used. Pragmatic markers are dialogically fecund in their use. They play an important role in the communicative process thanks not only to their dialogical value but also to their meta-status. They are meta-communicative, meta-linguistic and meta-pragmatic linking words that express our divergent viewpoints and positions in communication.

Key words: communication, pragmatic markers, Bakhtin

\section{Dialogiziranje sporazumevanja s pomočjo pragmatičnih označevalcev}

\author{
Povzetek
}

Članek obravnava meta-komunikativne značilnosti pragmatičnih označevalcev. Sporazumevanje razumemo z vidika Bakhtinovega koncepta dialogizma, ki ga razume kot dvosmerni process med udeleženci v sporazumevanju in govorom. Tako je beseda zgolj dialoška enota, ki obstaja in dobi pomen samo $\mathrm{v}$ kontekstu, $\mathrm{v}$ katerem se pojavi. Pragmatični označevalci so $\mathrm{z}$ vidika rabe dialoško plodoviti. $\mathrm{V}$ sporazumevalnem procesu igrajo pomembno vlogo tako zaradi svoje dialoške vrednosti kot tudi zaradi svojega meta-statusa. So meta-sporazumevalne, metajezikovne in meta-pragmatične vezalne/vezne beside, ki izražajo naše različne poglede in položaje v sporazumevanju.

Ključne beside: jezikoslovje, besediloslovje, intonacija 


\section{Dialogizing Communication through Pragmatic Markers}

\section{Theoretical Discussion and Literature Review}

\subsection{Communication and Dialogism}

Communication, as one of the most complex and sophisticated means that humanity has invented, helps us to profoundly explore human nature. It is a linguistic performance which enables people's perception of their feelings and attitudes, their interpersonal relations in society and reality in general. It is so vital a process that one cannot conceive of a society in the absence of this.

Certainly there are different ways through which interlocutors are capable of communicating with one another. For instance, they most often use gestures, facial expressions, intonation and other nonlinguistic means to accompany the communicative process. Most of the time, however, interlocutors rely on language itself to accomplish their interactions, and other, non-linguistic, means are only complementary to it. Therefore, while studying non-linguistic means is fascinating work, research into language aspects which facilitate communication is of primary importance.

Communicative acts that speakers produce in their linguistic interactions use the linguistic code and its elements as the main "substance". However, these acts or the communicative process as a whole are so dynamic, and at the same time so sensitive to the linguistic environment (context), that they are liable to be affected by some apparently invisible factors such as social, historical, spatial, interpersonal, functional, and discursive ones. From this perspective, in this paper we shall discuss how communication in general and certain linguistic items in particular, commonly known as pragmatic markers, are influenced by and related to the theory of dialogism as developed and elaborated by Mikhail Bakhtin in the 1920s and 1930s.

The majority of Bakhtin's theory is a reaction to, a direct antithesis of, Saussure's languagespeech model, according to which dichotomy language is the basic and the only dominant system enabling the individual communicative process. Saussure describes language as an objective abstract system of laws governing all the phonetic, grammatical and lexical forms, and interlocutors should regard this system as a closed circle dominated by fixed and undisputed rules. In addition, speech is so unsystematic that it cannot be studied efficiently. Saussure and other structuralists disregard the social view of language and ignore language as a fundamentally social phenomenon.

Bakhtin, whose dialogical theory considers verbal interaction a dialogue, neither denies the importance of semiotics and linguistic code nor that of systematic language description and the concepts of structuralism. What he champions is the indispensability of the dialogical and social communicative context of language, without which language would be practically empty, a means with little communicative values, simply a monological frozen system. Bakhtin (1986, 118) observes that 
The subject of linguistics is only the material, only the means of speech communication, and not speech communication itself, not utterances in their essence, and not the relationships among them (dialogic).... Linguistics studies only the relationships among elements within the language systems, not the relationships among utterances and not the relations of utterances to reality and to the speaker.

Thus, dialogism is a general framework for the perception of language with communicative values based on concrete language use and verbal interactions in social discourse, while its counter-theory, monologism as represented in the Saussurean view, deals exclusively with language representation in the individual, based on the language system, structure, rules and the linguistic code as part of semiotics as a science.

\subsection{Pragmatic Markers}

Various terms have been used by scholars in the literature to label those linking words or devices (e.g. therefore, so, although, but, etc.) which mark relations of cohesion and coherence in discourse. Halliday and Hasan (1976) and Sweetser (1990) use the term conjunctions, Schiffrin (1987) and Fraser (1996) use the term marker (the preferred term here) and, Van Dijk (1979) uses the label connectives. Although the terms differ and slightly different definitions have been given for them, they refer to the same linking devices, which, broadly speaking, have been divided into two types, according to the relation that they signal in discourse: semantic and pragmatic.

Relations between propositions in discourse are enabled through semantic markers, which only connect two related denoted facts; no speaker's intentions are conveyed through them, as in Example 1. On the other hand, pragmatic markers signal the relation of two related speech acts and are not part of the proposition of the sentence when they "convey the speaker's potential communicative intentions" (Fraser 1996). Thus, while semantic markers are linguistic devices used to fulfill cohesive relations in discourse, pragmatic markers are metalinguistic devices, which operate exactly the same way as do the former, but are "equipped" with pragmatic and communicative values, as in Example 2 and 3.

(1) He got tired of being turned away from bars and souvenir shops, so he left them back at the inn. (1996 News AssocPress) COCA

(2) Now I think Saddam does have still a loyal army and a very repressive security service, $s o$ it is not out of the question that he can end this problem. [open opposition to the regime] (1991 SPOK PBS_Newshour) COCA

(3) I don't see Gorbachev interest to keep those troops there. So it is a question of time before those troops are going to go. (1990 SPOK PBS_ Newshour) COCA

The classification of pragmatic markers is a very difficult task, for they make up an open class in which various parts of speech and structures may be included. However, among the common markers are: conjunctions, interjections, adverbials, performative expressions, complex expressions and particles 


\section{Purpose and Data Analysis}

\subsection{Specific purposes of our study}

The aim of the paper is to discuss the meta features of pragmatic markers as seen in the dialogical sphere. In our empirical and qualitative study, we wish to draw attention to these units that, among other functions such as enabling cohesion or coherence in discourse, dialogise communication because of the meta status they enjoy. We believe that this meta status consists in the fact that they appear not only as linguistic, pragmatic or communicative devices, but they go one step further by representing the existence of other voices in the discourse; by doing so pragmatic markers dialogise implicitly or explicitly by communicating economically with additional and possible world views. The hypothesis is that most pragmatic markers in communication work in the dialogical plan by forwarding the author's thesis, argument, intention, viewpoint and so on, as opposed to those of other present or absent interlocutors. For instance in Example 4,

(4) Tenet was too good a guy to lie intentionally, but unfortunately, his loyalty to the president and his inner circle was greater than his loyalty to his agency's analysis and, ultimately, his loyalty to the truth and his responsibility to have that truth heard.

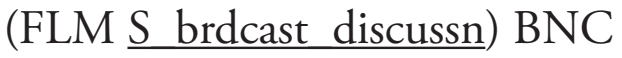

Is the author simply attempting to state that Tenet remained faithful to President Bush Sr.'s line and hid the details of the agency analysis by presenting it simply as a fact? Is this fact subordinate to his making the truth heard? Does the author try to persuade the audience? Or is he implying other divergent viewpoints in the text? Do we have key words that make the author's voice and that of the others heard in the passage? After all, is he communicating with someone? These are some of the questions that need to be answered.

\subsection{Data Collection}

As a basis for our study, we have explored two sources for our qualitative research, the 385million-word Corpus of Contemporary American English (COCA) and the 100-million-word British National Corpus (BNC), both freely available online. ${ }^{1}$ There is enough information in the examples included in the paper to provide the appropriate contextual environment for our analysis.

\subsection{Analysis}

Our research is mainly a qualitative study rather than a quantitative one. This means that our purpose has been to highlight the most important pragmatic markers, which are pragmatically and communicatively relevant in people's interactive processes. It was discovered that they have a role to play in the communication between interlocutors. We would like to begin our data discussion with performative verbs. 
(5) I don't think that he would be where he is today without her support and her help and her dedication to him. But also, like I said, I think they worked together and they were supportive of each other and that's why they're where they are today. (1990 SPOK ABC_2020) COCA

The discussion is about Mrs. Barbara Bush's contribution to President Bush Sr.'s performance in his career as a president. The speaker is both linguistically and pragmatically communicating with others by not only expressing his own opinion about her support for her husband him but also demonstrating his linguistic diversity and position in society. Evidence of his diversity is the unstated presence of additional possible voices which characterize the linguistic communicative process. The use of two pragmatic markers $I$ don't think and $I$ think is clearly indicative of the fact that the author is either recognizing other voices in the discussion or he is attempting to influence or persuade the audience, who may hold a different viewpoint. It should be noted that the first marker is not negating the proposition which follows it, but is simply accepting the fact that there may be other standpoints regarding the proposition. And I think is obviously pointing to persuasive reasons; otherwise the proposition alone (they worked together and they were supportive of each other) would merely be a fact, which in our context, is not necessarily so. Similarly, in Example 6,

(6) Well, I believe that everyone who lives in this world cannot but be impressed by the developments that have taken place in the Soviet bloc, in the eastern European countries. No doubt that this development might open a new era in global relations. But, I ask myself in which direction the danger of wars, years of wars, has been reduced, towards the Middle East, or towards NATO countries? To me, it's clear that if at all, there is a reduction of danger, is vis-à-vis NATO and European countries. (1990 SPOK ABC_Nightline) COCA

there would be no need for the speaker (George Bush Sr.) to defend his stance by making a strong assertion, using no doubt that and it's clear that, were it not for the fact that he expects his standpoint to meet with doubt. Pragmatically speaking, the voice of the author in the passage is dialogizing the communication and, as a result, is admitting that there is no unification as to his position about the opening of a new area in global relation and danger reduction. A longer extract, would have to provide more meta-pragmatic and meta-communicative discussions, which would rely mostly on pragmatic markers and their meta status.

Very similar to the meta pragma-communicative function of performative verbs discussed in Examples 5 and 6 are the adverbs of strong assertions. Common examples in our research, both in written and spoken texts, were surely, certainly and definitely, as in Example 7.

(7) Some institutions allow student and faculty involvement in social and political causes to excuse them from their educational responsibilities. Certainly, students should become interested in the social and political questions facing a free people, but they deserve to be taught that moral fervor is no substitute for diligent and systematic learning. (1990 ACAD AcademicQs) COCA 
The presence of communicative voices is also common among conjunctions and connectors, which are frequently used elements in texts. Their typology is rich, from conditions, concessions, results and so on. These pragmatic markers carry many pragmatic and communicative nuances, which we wish to highlight in our discussion.

Pragmatic markers in conditional clauses and sentences convey different dialogizing nuances and not only the condition to be fulfilled for an event to take place. Their frequent use in communication presupposes the unstated alternative possibility of an experience or occurence affirmed in the proposition of the clause, which the conditional pragmatic markers introduce. In Example 8,

(8) She was silent for a moment. "Look," I said. "The best thing for all of us is for me just to go back to London. If there is a solution to all this, that's where I'll find it. (A0F) $\mathrm{W}$ fict prose $\mathrm{BNC}$

the recognition of two possibilities as a solution, positive or negative, is to be deduced indirectly from the text. The silent interlocutor is being presented with two potential and exclusive alternatives, for which he should arrive at relevance values of the marker if in order to perceive the entire dialogically dominated meta-communicative features of the discourse.

Similarly, Example 9,

(9) By recognising that a number of subjects have a valid and useful contribution to make, some elements may be given less weighty consideration than others and the interrelationships may become lost. Unless there is a truly successful arrangement for the coordination of this teaching in schools, the current confusion will persist into the next generation. (APE $\underline{W}$ ac polit law edu) BNC

unless does not, of course, negate the propositional content of the sentence; rather it dialogizes the communication by inviting the interlocutor (again absent) to follow the procedural and not the conceptual communicative meaning the message contains. The pragmatic marker unless voices the pre-premise for the conclusion in the second clause. It also does not exclude the possibility that truly successful arrangements might not be made because thought of, as irrelevant by other standpoint holders. The author does acknowledge the indirect participation of others in his communicative process.

Concessive pragmatic markers, numerous in our database, concede or contrast situations introduced progressively or retrogressively. Anyway in Example 10,

(10) My own landlord did, in fairness, give me veiled offers of money (bribes) to move elsewhere but in all honesty I simply wasn't streetwise enough to figure out what exactly he had in mind. Also -- and I'm quite prepared to admit this -- because of all the problems I was having trying to find work, just at that moment I really didn't want the bother of hunting for a new home. That, if need be, could be sorted out at a later date. Anyway, there was hardly an atmosphere of trust between the two of us so the idea of me "dealing" with him was not a comfortable one. (A0F W_fict_prose) BNC 
is a pragmatically and communicatively powerful marker, which acts in two dimensions. In the first, it coherently structures the communication and in the second, anyway conveys elements of doubt about the preceding statements the interlocutor has made. The uncertainty and hesitation implicitly refer to the dialogical communicative situation, which allows for additional voices to be heard once the other interlocutor's perception is taken into account.

Another very frequent pragmatic marker of concession is however, which behaves slightly differently from anyway, but still contributes to the dialogical process of communication. Example 11 includes two instances of it.

(11) One of the most powerful forms of non-verbal communication is dress. The usual dress for Japanese businessmen is a dark suit, a white shirt and dark tie. However, most Japanese businessmen acquainted with foreigners have come to expect a certain variety within reasonable limits in the dress of foreign businessmen. It is not, therefore, expected that one should imitate the Japanese mode of dress. However, one should avoid extremes in dress which may cause uneasiness. For example, loud clothing will create the disturbing feeling among the Japanese businessmen that the foreigner has perhaps failed to take them as seriously as he might have, by failing to observe that the common practice in dress in Japan is some degree of formality. (K94 W commerce) BNC

The producer of the text is certainly in the informative realm of a monological process, through which the main purpose is to simply inform the audience about dressing as a powerful form of non-verbal communication. However, the passage is so detailed in its description and informativeness that the other interlocutor, for whom the fact possibly is unknown, is invited to assess the situation and to respond positively with the dominant voice in the discourse. The role of however in both cases is to add further information in the sentences they head and to pragmatically contribute to the interpretation of the same sentences as contradicting the previous ones. Here the reader or the interlocutor is involved in the cognitive process, in which he should make his evaluations and silently make his voice matter. Again, once we talk about people perception we are in the dialogical sphere of communication.

The pragmatic marker so appeared to be the most important pragmatic marker in the result/ consequence category. Example 12:

(12) It's really with regard to the advertising of tobacco products and I think we all agree that we do have a responsibility to protect children. And what we do from research is that children who smoke are more likely to smoke the brands that are heavily advertised and we also know that advertising reinforces smoking, it makes, makes people think that smoking is okay. So I think these are two very, very valid reasons why we ought to ban all forms of tobacco advertising. (FLM $\underline{S \text { brdcast discussn) }}$ BNC

The pragmatic marker so introduces the conclusion of the passage and it is supported by some premises. Here the speaker's intention is to convince the audience through rhetorical 
means and to express and forward his standpoint. Once involved in this persuasive process and expression of standpoint, we inevitably expect dialogised feedback from the interlocutor. Willingly, the speaker is dialogising his communicative act with the marker so.

Quite interestingly, pragmatic markers as dialogical elements almost always work together and in combination in discourse. They harmonize communication to perfection as in Example 13, in which they intensely dialogize the communicative environment.

(13) Many experts I've talked to and now, as we've seen, law enforcement officials, say that educating people about the dangers of drugs is maybe the best way to combat the problem and treat it as a medical problem, a health problem, not a criminal problem. Tobacco, according to the Public Health Service, is addictive and legal and kills over 300,000 Americans each year, but it's very unlikely to be outlawed because that could make things worse. However, it is now becoming socially unacceptable. People are being educated away from tobacco, so education is doing what prohibition is not able to do. And that same approach might well be applied to what is now illegal drug use. (1990 SPOK ABC_2020) COCA

Example 13 is a typical argumentative passage extracted from a TV programme, in which the interlocutors are discussing the progress made by the Bush administration in the fight against illegal drug use. The speaker highlights the administration's inefficiency in reducing the number of drug users and preventing drug dealing. He is continuously engaged in a dialogue with the other interlocutor, who reports on successful law enforcement and positive results obtained. At the same time, the speaker is attempting to persuade the audience to share his viewpoint. Therefore, the dialogical realm of the discourse acts in a parallel and simultaneous way with two targeted interlocutors.

The conclusion, which is introduced retrogressively, is supported directly by various subconclusions and premises throughout the extract, which would hardly stand in logical and coherent relation, were it not for the pragmatic markers (but, because, however, so, and). Fortunately, there are these markers that specifically refer to standpoints and argumentation by making the discourse even more socialized, externalized and functionalized ${ }^{2}$ as well. Also, they clarify the three most important properties of the argumentation, the structure, meaning and the speaker's intentions in argumentation. Van Eemeren et al. $(1996,13)$ notes that "the fewer the number of verbal pointers, the more it will be necessary to make use of verbal and nonverbal contextual clues".

The mere fact that the pragmatic markers discussed above appear as textual devices in the surface structure of the discourse does not mean that they would act the same way in the underlying structure. It is precisely here that they dialogise the argumentation and, in doing so, the different voices (expectations, responses, evaluations etc) become concrete and could be heard. The marker but, does not only show contrast between the two utterances it relates

Three concepts introduced by Van Eemeren et al., 2007. 
(tobacco being addictive and its unlikelihood to be outlawed), but also "resonates" the speaker's voice with other ones, although not directly present in the text. The same thing could be said for the because that has two purposes: to introduce the premise and to clearly express the speaker's strong doubt that outlawing tobacco is the right choice. However socializes the unacceptability of smoking, and so opens a "conflict" between education and probibition supporters. Lastly, and functionalizes and externalizes the conclusion the speaker wishes the other to reach as well.

\section{Conclusions}

Communication is not simply the use of the language abstract system, nor a process which is fulfilled in isolation. It is most complex and comprises a number of metalinguistic factors in the social dimension, where linguistic interaction is accomplished. By nature, the communicative process is socialized and externalized in a dialogical fashion. A single voice could only be heard if it is combined with a complex choir of divergent voices in communication. It is deeply and fundamentally cooperative in linguistic interactions and in the presence of opposing voices, whether stated or absent in discourse.

It was also noticed that the linguistic message of communication is not the only purpose in the communicative process, which necessarily seeks a parallel referential value for the social and contextual phenomena resting outside the linguistic communicative acts themselves. Pragmatic markers, through their metalinguistic function, bridge the external and internal linguistic world of the interlocutors in the communication. They dialogise communication by expressing our divergent standpoints, evaluations and responses, which emit a high level of resonance in the dialogical sphere and a complex deictic value. The empirical study revealed that communication is dialogised, among other means, through the strategic maneuvering and use of pragmatic markers, which, to different extents, proved to be metalinguistically, metapragmatically and meta-communicatively indispensable devices. Dialogised communication through pragmatic markers demonstrate various and rich nuances of discussion, depending greatly on social and functional features. 


\section{Bibliography}

Bakhtin, M.M. 1986. Speech Genres and Other Late Essays. Trans. Vern W. McGee. Ed. C. Emerson and M. Holquist. 1st ed. Austin, TX: University of Texas Press.

Fraser, B. 1999. What are Discourse Markers? Journal of Pragmatics 31: 931-52.

Halliday, M.A.K., and R. Hasan. 1976. Cohesion in English. London: Longman.

Holquist, M. 2002. Dialogism: Bakhtin and His World. London: Routledge.

Saussure, F. de. 2002. Kurs i Gjuhësisë së Përgjithshme. Trans. R. Ismaijli. Tirana: Shtëpia Botuese Dituria.

Schiffrin, D. 1987. Discourse Markers. Cambridge: Cambridge University Press.

Sweetser, E. 1990. From Etymology to Pragmatics: Metaphorical and Cultural Aspects of Semantic Structure. Cambridge: Cambridge University Press.

Van Eemeren, F.H., et al. 2007. Argumentative Indicators in Discourse: A Pragma-dialectical Study. Dordt: Springer.

- - - 1996. Fundamentals of Argumentation Theory: A Handbook of Historical Backgrounds and Contemporary Developments. Mahwah, NJ: Lawrence Erlbaum Associates.

Van Dijk, T.A. 1979. Pragmatic Connectives. Journal of Pragmatics 3: 447-56. 